\title{
O'CONOR (TRANSABDOMINAL) REPAIR: IS IT ALWAYS NECESSARY TO INTERPOSE A FLAP IN SIMPLE VESICO-VAGINAL FISTULA? A COMPARATIVE STUDY
}

\author{
Asma Rizwan, Qamar Zia, Adil Khurshid, Mudassar Sajjad*, Muhammad Nawaz**, Muhammad Akmal*, Faran Kiani** \\ Combined Military Hospital Lahore/National University of Medical Sciences (NUMS) Pakistan, *Combined Military Hospital Malir/National \\ University of Medical Sciences (NUMS) Pakistan, **Armed Forces Institute of Urology/National University of Medical Sciences (NUMS) \\ Rawalpindi Pakistan
}

\begin{abstract}
Objective: To assess morbidity and success of transabdominal ( $\left.\mathrm{O}^{\prime} \mathrm{Conor}\right)$ repair of vesicovaginal fistula with or without interposition of flap between vagina and urinary bladder.

Study Design: Prospective comparative study.

Place and Duration of Study: Armed Forces Institute of Urology, Rawalpindi, from Mar 2016 to Jan 2019.

Methodology: Fifty five patients were randomized into group A \& B by lottery method. An inclusion criterion was single fistulous opening of $\leq 3 \mathrm{~cm}$. Complex and recurrent fistulae were excluded. Patients in group A underwent $\mathrm{O}^{\prime}$ Conor repair without interpositional flap while in group B vesicovaginal fistulae were repaired with flap interposition.

Results: Twenty two patients were randomized in group A while 27 in group B. Mean age of patients was 41.65 \pm 11.93 years. Gynecological and obstetrical surgery was the main cause of fistula. Mean duration of surgery was $162.7 \pm 18.49$ minutes. Per-operative ureteric catheterization was done in $9(16.8 \%)$ patients. Seventeen $(30.6 \%)$ patients had paralytic ileus. There was transient fever in $4(7.6 \%)$ of cases and wound infection was seen in $3(5.8 \%)$ of patients. Mean hospital stay was $3.4 \pm 2.3$ days. Cystogram was done in $35(64.5 \%)$ of patients before the removal of per-urethral catheter. The overall success rate was $92.9 \%$. Ten $(18.2 \%)$ of patients developed denovo urgency which was managed conservatively. There was no statistical difference in both groups in terms of morbidity and success.

Conclusion: In simple Vesico-vaginal fistulae repair, interposition of flap can be omitted and it does not affect the outcomes in terms of success and morbidity.
\end{abstract}

Keywords: Female urogenital disease, Urinary bladder fistula, Vesico-vaginal fistulas.

This is an Open Access article distributed under the terms of the Creative Commons Attribution License (http://creativecommons.org/licenses/by/4.0), which permits unrestricted use, distribution, and reproduction in any medium, provided the original work is properly cited.

\section{INTRODUCTION}

An abnormal epithelial lined communication between vagina and urinary bladder is vesicovaginal fistula (VVF). The earliest account of this debilitating pathology dates back to $2050 \mathrm{BC}^{1}$. The incidence and etiological factors of VVF differ in developed and under developed countries. The overall reported incidence of VVF is 0.4$3.2 \%{ }^{2}$. The causes of VVF include pelvic surgery, prolonged obstructed labour, radiotherapy, pelvic malignancies, tuberculosis, foreign body and pelvic trauma ${ }^{3}$.

James Marion Sims described VVF repair using silver wires in $1852^{4}$. Since then there have

Correspondence: Dr Qamar Zia, Dept of Urology, Combined Military Hospital, Lahore Pakistan

Received: 09 Dec 2019; revised received: 26 Mar 2019; accepted: 30 Mar 2020 been many modifications in surgical treatment of VVF. Transabdominal, transvaginal, laparoscopic and robot assisted approaches have been described. The choice of surgical approach depends upon location and size of fistula, available vaginal space, need for ancillary procedures, experience of surgeon and ease of placing inter-positional flaps ${ }^{5}$. Traditionally VVF are repaired with inter-positional flap between vagina and urinary bladder to segregate the suture lines. Different flaps have been used for both transabdominal and transvaginal approaches like peritoneum, omentum, gluteal muscle, rectus abdominal muscle, labial fibro-fatty tissue (Martius flap) and urachus 6 .

VVF is a big health related issue. It has both physical and psychological implications ${ }^{7}$. Most of 
the women affected by VVF are young and are severely affected in terms of appearance, hygiene, personal and social relations ${ }^{8}$.

In repair of simple VVF inter-positional flap is not always required. Different non randomized studies have compared the rate of success when repairing VVF with or without interposing flap9. The over-all reported success rate of VVF repair is $90-95 \%$. However different success rates have been reported when comparing VVF repair with or without interposing flap ${ }^{10}$.

In this prospective comparative study, we have compared the success and complication rates of O'Conor (transabdominal) repair of simple VVF with or without using the inter-positional flap. At times it becomes very difficult to mobilize the flap deep into pelvis and it causes increase in operating time.

\section{METHODOLOGY}

This prospective comparative study was conducted at Armed Forces Institute of Urology Rawalpindi, Pakistan from March 2016 and Jan 2019. Ethics approval was obtained from institutional ethical review board (IRB/AFIU-293/ 2016). Inclusion criteria included patient with single VVF of $\leq 3 \mathrm{~cm}$ size (simple VVF). Patients with fistula $>3 \mathrm{~cm}$ size, multiple openings, previously operated, malignant etiology, bladder stones, poor continence mechanism and pelvic trauma were excluded from this study. Verbal and informed written consent was obtained for randomization. Fifty five patients consented for randomization and were divided into 2 groups using lottery method. Clinical com (statistic sample size calculator) was used to calculate sample size. In group-A 28 patients underwent transabdominal (O'Conor) repair of VVF without interposition of flap while in group-B VVF was repaired transabdominally with flap interposition in 27 patients.

Cystoscopy was performed in all patients to determine number, site and size of fistula. Assessment of bladder mucosa and capacity was done. In few patients ureteric catheters were retained when fistulous opening was very close to ureteric orifices.
Transabdominal repair was done using $\mathrm{O}^{\prime}$ Conor technique. Infra-umbilical midline incision was made. Bladder was bi-valved from dome till fistulous opening. Plane between bladder and vagina was created using sharp dissection. A minimum of $2 \mathrm{~cm}$ margin clearance was achieved. Vaginal rent was repaired transversally using interrupted 2/0 vicryl sutures. In group B, an omental or peritoneal flap was interposed between vagina and bladder wall. It was fixed over vaginal repair using 4/0 vicryl. No flap was used in group A. In both groups bladder was repaired in 2 layers. Supra-pubic catheter (16 Fr) was placed in all patients. Bladder was filled with diluted methylene blue to ensure water-tight closure ${ }^{18}$. Fr per urethral (PU) Foley catheter was retained.

Patients were monitored for early complications like post-operative pain, fever, paralytic ileus, abdominal distension, intestinal obstruction, hemoglobin and creatinine levels. Patients were discharged after 3-6 days. All patients were advised to take tablet Solifenacin $10 \mathrm{mg}$ (once daily) and stool softeners. First review visit was planned at week 1 . SPC was removed after 2 weeks and PU catheter after 3 weeks. Cystogram was done in selected patents. Success was defined as no leak after 72 hours of removal of PU catheter.

All the data was entered in a specially designed proforma and Statistical analysis was performed by using Predictive analytics software PASW statistics 18 (formerly SPSS Statistics). Mean \pm SD was calculated for quantitative variables. Frequency and percentage were calculated for qualitative variable.

\section{RESULTS}

A total of 28 patients were randomized in group A while 27 were randomly selected for group B. Mean age of patients was $41.65 \pm 11.93$ years. The etiology of VVF was shown in table-I.

Mean duration of surgery was $162.7 \pm 18.49$ minutes. Per-operative ureteric catheterization was done in $9(16.8 \%)$ of cases. There was no statistically significant difference in blood loss and change in creatinine levels post operatively. 
$17(30.6 \%)$ patients had paralytic ileus. There was transient fever in $4(7.6 \%)$ of cases and wound infection was seen in $3(5.8 \%)$ of patients. One patient in group B developed intestinal obstruction which was managed conservatively. Mean hospital stay was $3.4 \pm 2.3$ days. Cystogram was done in $35(64.5 \%)$ of patients before the removal of PU catheter. The overall success rate was $92.9 \%$. Ten $(18.2 \%)$ of patients developed de-novo urgency which was managed conservatively in all patients except 1 in group $B$ who required intra vesical Botox injection. The comparison of these results between group $A$ and group $B$ is shown in table-II. No statistical difference was found in morbidity and success rate amongst group A \& B.

Table-I: Causes of vesicovaginal fistula.

\begin{tabular}{l|c}
\hline Cause & n (\%) \\
\hline Hysterectomy & $31(53.6)$ \\
\hline Obstructed Labour & $14(31.8)$ \\
\hline Caesarian Section & $8(14)$ \\
\hline Urological & $2(0.6)$ \\
\hline
\end{tabular}

In 1967, Turner-Warwick et al13, described the principles of omental flap mobilization based on the right gastroepiploic artery emerging from the greater curvature of the stomach. Gousse et al, evaluated the use of interposition flaps among 29 patients with benign etiology and 8 patients with malignant etiology. They showed a $100 \%$ success rate when the interposition flap was used, as compared to $63 \%$ success rate when a tissue flap was not used 8 . Failure was in patients with VVF of malignant etiology and complex fistulae. In secondary analysis if only simple fistulae were evaluated the success rate rose to $90 \%$. This is similar to our study.

Interposition flaps are not routinely utilized when the surrounding tissues appear healthy and well-vascularized, such as in a benign etiology. Thus, interposition flaps would be a valuable adjunct in the reconstruction of malignant and radiation fistulas. In complex and complicated fistulae, interpositional flaps are essential.

Graft interposition is not indicated in all

Table-II: Comparison of results between group a and group $b$.

\begin{tabular}{l|c|c|c}
\hline Variables & \multicolumn{2}{|c|}{ Comparison } & $p$-value \\
\hline Groups & $\mathrm{A}$ & $\mathrm{B}$ & \\
\hline Age (Years) & $40.11 \pm 12.47$ & $43.26 \pm 11.36$ & 0.33 \\
\hline Duration of surgery (Minutes) & $166.35 \pm 21.78$ & $158.92 \pm 13.72$ & 0.13 \\
\hline Paralytic ileus (n) & 7 & 9 & 0.84 \\
\hline Wound Infection (n) & 3 & 2 & 0.73 \\
\hline Hospital Stay (days) & $3.6 \pm 3.2$ & $3.9 \pm 4.1$ & 0.63 \\
\hline Leak (Failure, $\mathrm{n}$ ) & 2 & 1 & 0.59 \\
\hline De Novo Urgency & 4 & 6 & 0.14 \\
\hline
\end{tabular}

\section{DISCUSSION}

The most common cause of VVF in developed countries is pelvic surgery e.g. hysterectomy while in developing countries prolonged obstructed labour is the leading cause ${ }^{11}$. Contrary to various studies from Pakistan, we found hysterectomy as the most common cause. This difference can be explained by the fact that AFIU is a tertiary care hospital and receives cases from centers with relatively good obstetric care. Arshad et $a l^{12}$, also found the similar patternof etiological factors in their study from same institute. cases of VVF repair ${ }^{14}$. No high-quality evidence supports the routine use of graft interposition. The use of grafting in obstetric VVF has significantly declined. Relying on watertight, tensionfree, uninfected multilayer closure is often sufficient $^{15}$. Graft interposition is indicated in cases of recurrent, RT-induced, and long-standing VVFs. A variety of flaps have been used in abdominal repairs including omentum and peritoneum covering the bladder dome ${ }^{16}$. In group B we used similar flaps to interpose between vagina and urinary bladder. 
Mubeen et al, reported $87 \%$ success rate ${ }^{17}$, while in another of their study reported $81 \%$ success rate in 11 patients ${ }^{18}$, and concluded that VVF can be best managed following basic surgical principles like adequate exposure, identification of structures, wide mobilization, tension-free closure, good haemostasis and uninterrupted bladder drainage.

A study published from Lahore by Hafeez et $a l$, comprising 14 patients reported $85 \%$ success rate $^{19}$, and noted that transabdominal repair was the most successful method of repair. One study of 70 patients had $85 \%$ success rate. Shiekh et al20, used omental interposition and reported $85 \%$ and $100 \%$ success rate with transvaginal and transabdominal approaches; transabdominal being more successful. It emphasized on the use of omental interposition for VVF repair with transabdominal approach. In these studies, the complexity of VVF was not defined and had limitation of being retrospective.

Morbidity and success rate do not differ in group A and group B in this study. Singh et al 21 , found similar results in their randomized comparative study. They compared not only transabdominal but also the transvaginal approach with or without interpositional flap and found no difference. They found statistically insignificant increase in blood loss and post-operative abdominal pain in patients treated with flap interposition. We did not find such trend in our study although the success rate was similar in both groups.

\section{CONCLUSION}

In simple VVF repair, interposition of flap can be omitted and it does not affect the outcomes in terms of success and morbidity.

\section{CONFLICT OF INTEREST}

This study has no conflict of interest to be declared by any author.

\section{REFERENCES}

1. Zacharin RF. New York: Springer-Verlag/Wien; 1998. Obstetric Fistula.

2. Malik MA, Sohail M, Malik MT. Changing trends in the etiology and management of VVF. Int J Urol 2018; 25(4): 25-19.
3. Ichihara K, Masumori N, Takahashi S, Miyao N, Kato R. Bladder Neck rupture and vesico-vaginal fistula, associated with pelvic fracture in females. Low Urin tract Symptoms 2015; 7(3): 115-17.

4. Sims JM. On the treatment of vesico-vaginal fistula 1852. Int Urogynecol J Pelvic Floor Dysfunct 1998; 9(1): 236-48.

5. Espinoza AR, Cardozo A, Rojas C, Petit M, Lopez V. Vaginal repair of vesico-vaginal fistula: Experience at tertiary care center in Venezuela. Arch Esp Urol 2019; 72(4): 398-05.

6. Farahat YA, Elbendary MA, Elganaal OM, Tawfik AM, Bastawisy MG, Rawadan MH, et al. Application of small intestine mucosa graft for repair of complicated vesico-vaginal fistula. A pilot study. J Urol 2012; 188(5): 861-64.

7. Hesselman S, Bergman L, Högberg U, Jonsson M. Risk of fistula formation and long-term health effects after a benign hysterectomy complicated by organ injury: a population-based register study. Acta Obstet Gynecol Scand 2018; 97(5): 1463-70.

8. Barageine JK, Beyeza-Kashesya J, Byamugisha JK, Tumwesigye NM, Almroth L, Faxelid E. "I am alone and isolated": a qualitative study of experiences of women living with genital fistulain Uganda. BMC Women's Health 2015; 24(15): 73-78.

9. Singh V, Sinha RJ, Sankhwar SN, Sinha SM, Vastal P, Jain V. Transvaginal repair of complex and complicated vesico-vaginal fistulae. Int J Gynaecol Obstet. 2011; 144(1): 51-55.

10. Evans DH, Madjar S, Politano VA, Bejany DE, Lynne CM, Gousse AE. Interposition flap in transabdominal vesico-vaginal repairs: Are they really necessary. Urology 2001; 57(4): 670-74.

11. Theofanides MC, Sui W, Sebesta EM, Onyeji H, Matulay JT, Chung DE. Vesicovaginal fistulas in the developed world: an analysis of disease characteristics, treatments, and complications of surgical repair using the ACS-NSQIP database. Neurourol Urodyn 2017; 36(5): 1622-28.

12. Mehmood A, Alvi MS, Rana S, Razziq S, Siddiq L, Shah MY. Vesico-vaginal fistula: Interpositional flap, a key to success. J Ayub Med Coll 2009; 21(3): 29-31.

13. Turner-Warwick RT, Wynne EJC, Handley-Ashken M. The use of the omental pedicle graft in the repair and reconstruction of the urinary tract. Br J Surg 1967; 54(5): 849-53.

14. Miklos JR, Moore RD, Chinthakanan O. Laparoscopic and robotic-assisted vesicovaginal fistula repair: a systematic review of the literature. J Minim Invasive Gynecol 2015; 22(5): 727-36.

15. Beardmore-Gray A, Pakzad M, Hamid R, Ockrim J, Greenwell T. Does the Goh classification predict the outcome of vesicovaginal fistula repair in the developed world? Int Urogynecol J 2017; 28(6): 937-40.

16. Mohr S, Brandner S, Mueller MD, Dreher EF, Kuhn A. Sexual function after vaginal and abdominal fistula repair. Am J Obstet Gynecol 2014; 211(1): 741-46.

17. Mubeen RM, Naheed F, Anwar K. Management of vesicovaginal fistulae in urological context. J Coll Physicians Surg Pak Jan 2007; 17(3): 28-31.

18. Mubeen RM, Naheed F, Ashraf R, Malik AA. Surgical management of simple Vesicovaginal fistulae. Ann King Edward Med Uni 2005; 11(1): 27-29.

19. Hafeez M. Profile and repair success of Vesico-Vaginal fistula in Lahore. J Coll Physicians Surg Pak Mar 2005; 15(2): 142-44.

20. Shaikh AR, Memon AA, Shaikh S, Shaikh NA, Shaikh SN, Shaikh AF, et al. Vesico-vaginal fistula abdominal repair versus repair via vaginal route. Professional Med J 2011; 18 (2): 354-60.

21. Singh V, Mehrotra S, Bansal A, Akhtar A, Sinha RJ. Prospective randomized comparison of repairing vesicovaginal fistula with or without the interposition flap: Results from a tertiary care institute in Northern India. Turk J Urol 2019; 45(5): 377-83. 